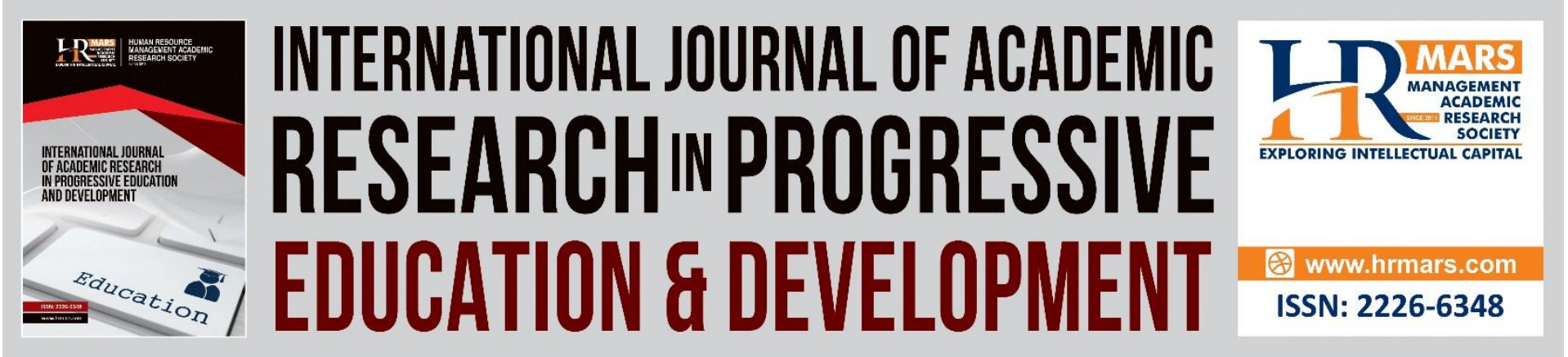

\title{
New Practices and New Norms: How Online Learning Effect the Quality of Visual Art Education (VAE) Pre-service Teacher's Learning Process?
}

\author{
Mohd Khairezan Rahmat, Wing K. Au, Nur Nabihah Mohamad Nizar
}

To Link this Article: http://dx.doi.org/10.6007/IJARPED/v10-i3/10820

DOI:10.6007/IJARPED/v10-i3/10820

Received: 16 June 2021, Revised: 20 July 2021, Accepted: 05 August 2021

Published Online: 28 August 2021

In-Text Citation: (Rahmat et al., 2021)

To Cite this Article: Rahmat, M. K., Au, W. K., \& Nizar, N. N. M. (2021). New Practices and New Norms: How Online Learning Effect the Quality of Visual Art Education (VAE) Pre-service Teacher's Learning Process. International Journal of Academic Research in Progressive Education and Development, 10(3), 467-478.

Copyright: (C) 2021 The Author(s)

Published by Human Resource Management Academic Research Society (www.hrmars.com)

This article is published under the Creative Commons Attribution (CC BY 4.0) license. Anyone may reproduce, distribute, translate and create derivative works of this article (for both commercial and non-commercial purposes), subject to full attribution to the original publication and authors. The full terms of this license may be seen

at: http://creativecommons.org/licences/by/4.0/legalcode

Vol. 10(3) 2021, Pg. 467 - 478

Full Terms \& Conditions of access and use can be found at http://hrmars.com/index.php/pages/detail/publication-ethics 


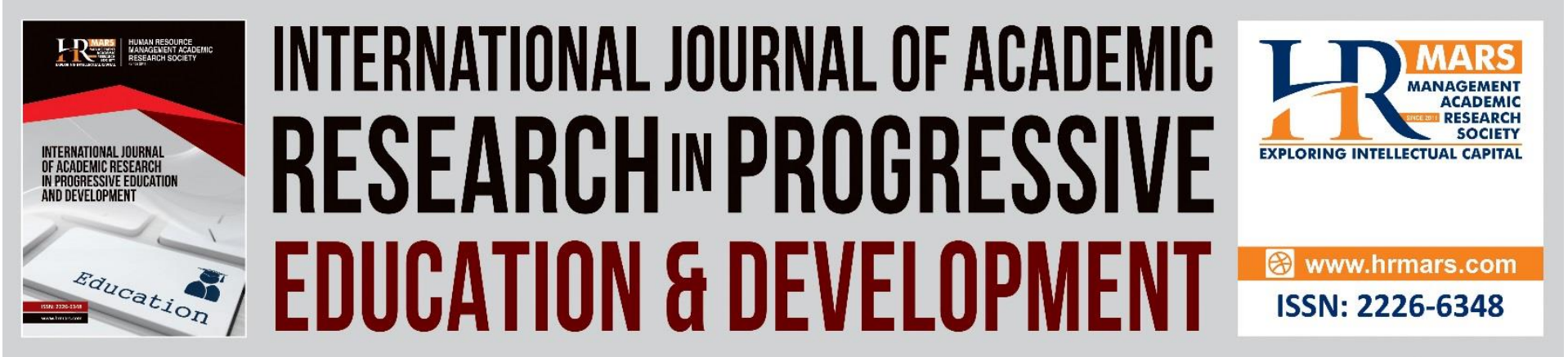

\title{
New Practices and New Norms: How Online Learning Effect the Quality of Visual Art Education (VAE) Pre-service Teacher's Learning Process?
}

\author{
Mohd Khairezan Rahmat ${ }^{1}$, Wing K. Au², Nur Nabihah \\ Mohamad Nizar ${ }^{3}$
}

Faculty of Education, Universiti Teknologi MARA (UiTM), Malaysiaa, ${ }^{1,3}$, School of Education, University South Australia (UniSA) ${ }^{2}$

Email: mohdk787@uitm.edu.my ${ }^{1}$,wing@unisa.edu.au², murnabihahnizar91@gmail.com³

\begin{abstract}
The sudden outbreak caused by the COVID-19 has challenged the global education ecosystem. Similar to other subject area, the Visual Art Education (VAE) conventional face-to-face teaching were replaced with online approach. This dramatic transformation has undoubtedly caused modification of pre-service teacher's understanding and mind-set toward possibilities of adopting online learning approaches in art classrooms. Recognizing the potential of this situation, this study was set to investigate the effect of online learning toward VAE pre-service teachers' quality of learning. Conversely, pre-service teacher's perceived usefulness, perceived ease of use, and attitude toward their behavioral intention to adopt online learning in art classrooms were also tested. A total of 122 VAE pre-service teachers from Malaysia public university were the respondents of this study. The SPSS was employed to analyzed data, while the Partial Least Squares (PLS) of variance-based Structural Equation Modelling (SEM) was used to test the research hypotheses of the study. Findings of the study have indicated that the VAE pre-service teachers' quality of learning was affected from online learning. The study also suggests that the VAE teachers' perceived usefulness, perceived ease of use, and attitude were able to explain 65.3 percent of the variance toward their intention to adopt online learning in art classrooms. Hence, it is envisaged that the findings from this study will contribute toward understanding of impact of online learning toward pre-service teacher's training process. It is also hoped that this study will act as a guide for teachers training institutions and the Ministry of Education toward establishing a standard of successful online learning adoption.
\end{abstract}

Keywords: Online learning, Visual Art Education (VAE), pre-service teachers, Structural Equation Modelling (SEM), Technology Acceptance Model (TAM)

\section{Research Context}

Since the last month of the year 2019, the whole world was badly affected by a novel corona virus, known as COVID-19. Likewise, other aspect of everyday life, the COVID-19 
outbreak has had a serious impact on education system. Under the efforts to curb the spread of the virus, all educational institutions were ordered to closed. Further, teachers' conventional face-to-face instruction were diverted to more flexible mode through online learning approach. This paradigm shift has undoubtedly caused compulsory modification of teacher's teaching approach and created new norms of learning among students. As nobody knows when this pandemic will be over, pre-service teachers must firstly be equipped and trained with appropriate knowledge and skills of adopting online teaching and learning.

As any other subject areas, the Visual Art Education (VAE) teachers are also expected to explore and utilized the full potentials of online teaching and learning. The changes caused by the pandemic outbreak has provide opportunities for the VAE teachers to enhance and transform art learning, by which will extend the subject pedagogy. Through the VAE teacher's online teaching strategies, students will actively involve in constructing, processing, evaluating and synthesizing their ideas (Hogan et al., 2020), which resulting new ways of promoting, perceiving and practicing art (Sands \& Purtee, 2018). By adopting online learning, art classrooms will provide opportunities for VAE pre-service teachers to construct their own knowledge and improve problem-solving skills through simulation, manipulation and creative expression. However, despite those mentioned advantages, previous studies have reported that many VAE teachers have not adopted it optimally and without knowing its value and necessity towards successful art instruction (Khairezan, 2020). Other studies also did highlight VAE teachers' limited knowledge and skills on adopting online learning due to limited and irrelevant training courses (Berrocoso et al., 2020). These unpleasant situations have highlighted the importance to determine the effect of online learning toward the VAE preservice teacher's quality of learning.

Conversely, the adoption of online teaching and learning into art classrooms should also consider on the VAE pre-service teacher's point of views. Act as an agent of education change, the VAE pre-service teachers' perception and attitude toward online teaching and learning might resulted on their intention to adopt it into their future instruction process. As suggested by (Sajnani et al., 2020), the successful online adoption does not by simply adding it into teaching and learning process, instead it involved a complex innovation acceptance and new technological-pedagogical practices. Hence, addressing the VAE pre-service teachers' challenges to adopt online teaching and learning will help to determine their intention to adopt it into their future instructional process (Taylor-Guy \& Chase, 2020). With this regard, the present study tries to examine the VAE pre-service teacher's perceived usefulness (PU), perceived ease of use (PEOU), and attitude (ATT) toward their behavioral intention (BI) to adopt online learning in art classrooms. In light of published research that highlight similar research aim, especially in the VAE subject area, findings from this study hope to foresee preservice teacher's permanent change, in which impart education system in the post COVID-19 scenario.

\section{Online Teaching in Art Classrooms}

The necessity to embarked into online learning can be sees as a catalyst that provides new ways to enhance and transform art learning. Through its flexibility and dynamicity, online teaching and learning approach will allows art students to construct their own knowledge and to create their own meaning and solutions. The adoption of online teaching and learning 
approach also has provide a huge impact on art students' creative abilities and critical thinking skills. Student can venture into more real experiences through the processes of simulation and manipulation that never been highlighted before in conventional art classrooms. Further, as medium for exploring ideas, online learning enables students to modify, manipulate and develop their ideas in a supportive environment. By enhancing students' ability to perform such tasks, online teaching and learning approach also will decrease students' anxieties about self-expression, and to expand their creativity.

Although those highlighted statements have suggested the potentials of online teaching and learning approach in art classrooms, the migration from conventional to online teaching and learning approaches in art classrooms were reported to be far from its target (Sia \& Abbas, 2020). For instance, a study by Pratama \& Surahman (2020) has reported that the adoption of online learning in art classroom during pandemic are difficult and challenging, as it restrains student's creativity, artistic expression and understanding of art forms. Another biggest challenge in adopting online learning is to embody positive emotional engagement in learning among students (Dilmac, 2020). The positive emotion helps to motivate and enhance students' creative thinking, while negative emotion can undermine their learning process. Another biggest challenge is to embody positive emotional engagement in motivating and enhancing students' creative thinking, as negative emotion can undermine their learning process (Dilmac, 2020). Those research findings have called for the VAE teachers to change their mindset and make compulsory modification of their conventional instruction process (Ribeiro, 2020). Hence, by identifying the VAE teacher's perceived usefulness (PU), perceived ease of use (PEOU) and attitude (ATT) toward their behavioral intention (BI) to adopt online learning have become the aim of the study. It is anticipated that findings from this study will help to determine strategies for intervention and providing guidelines for successful online adoption in art classrooms, especially in recognizing it as new practices and new norms of teaching and learning among pre-service VAE pre-service teachers.

\section{Research Hypotheses}

Over the past three decades, numerous theories and models have been put forward to ensure the successful integration of online teaching and learning among students and teachers. As proposed by Davis (1989) in Technology Acceptance Model (TAM), individuals' PU and PEoU has a direct influence towards their ATT in predicting the intention of using proposed technology. The previous studies show consistency relation result that whenever each time an effect on ATT is found, it is positive. Nadlifatin et al. (2020) highlighted the significant relationships between PU and ATT in aspects of online and physical learning in developing countries. This finding showing that in the developed countries, having a pleasant feeling toward online and physical learning is determined greatly by how they see its usefulness and to what extent it able to increase students' performance in learning. Similar findings also were found in determining individuals' ATT towards various online learning approach including web-based learning (Azman, et al., 2020)), mobile learning (Mukminin et al., 2020) and augmented reality learning system (Nizar et al., 2020), Within the same context of study, Sukendro, et al. (2020) found that PEoU as a main factor in determining students' ATT in using online learning during the pandemic. This shred of evidence that the students able to perceive positive attitude when e-learning is user-friendly/ is perceived to be user friendly and thus directly increase their intention to use the e-learning during pandemic. 
Nadlifatin et al. (2020) through their model confirmation and Nizar et al. (2020) through their exploratory study confirmed this finding.

Study by Thongsri et al (2019) highlighted the important of PU as main factor in increasing the students' BI to adopt online learning. However, their study does not able to confirm the relationship between PEoU use and BI. This finding indicated that, students are more likely to adopt online learning when they believe it able to improve their learning's efficiency but the high cognitive load hindering their intention to adopt online learning thoroughly. Despite that, (Nadlifatin, et al., 2020; Yeop, et al., 2019) confirmed the relationship between PU and PEoU towards $\mathrm{BI}$ in their study. Regarding ATT, Aburagaga et al. (2020) suggests that the high degree of positive feelings towards technology able to enhance users' intention to use the technology. The fact that ATT towards BI to use online learning can be achieve by emphasizing the easiness of use (Nadlifatin, et al., 2020) and the benefits gain among students while using it (Sukendro, et al., 2020). The direct relationship between $\mathrm{Pu}$, PEoU and ATT towards BI were confirmed by Shao (2019) in his emperical study.

Based on above discussion, it is revealed the important of Pu, PEoU, ATT as predictors and most of the findings proved its correlations in addressing students' intention to use online learning. Rooted from Technology Acceptance Model (TAM), this study hence has determined the VAE teacher's perceived usefulness (PU), perceived ease of use (PEoU), and attitude (ATT) as main factors that may influence their behavioral intention (BI) to adopt online learning in art classrooms. Six hypotheses associated with those constructs were then generated in determining factors that might influence the VAE pre-service teacher's intention to adopt online learning. There are:

$\mathrm{H}_{1}$ : The pre-service Visual Art Education (VAE) pre-service teachers' perceived usefulness (PU) has a significant influence on their perceived ease of use (PEOU) towards adopting online learning

$\mathrm{H}_{2}$ : The pre-service Visual Art Education (VAE) pre-service teachers' perceived usefulness (PU) has a significant influence on their attitude (ATT) towards adopting online learning $\mathrm{H}_{3}$ : The pre-service Visual Art Education (VAE) pre-service teachers' perceived usefulness (PU) has a significant influence on their behavioral intention (BI) to adopt online learning $\mathrm{H}_{4}$ : The pre-service Visual Art Education (VAE) pre-service teachers' perceived ease of use (PEoU) has a significant influence on their attitude (ATT) towards adopting online learning $\mathrm{H}_{5}$ : The pre-service Visual Art Education (VAE) pre-service teachers' perceived ease of use (PEoU) has a significant influence on their behavioral intention (BI) to adopt online learning $\mathrm{H}_{6}$ : The pre-service Visual Art Education (VAE) pre-service teachers' attitude (ATT) has a significant influence on their behavioral intention (BI) to adopt online learning

\section{Research Methodology}

This study employed a quantitative research method, where data were gathered through a self-administrated online survey. In order to achieve a good response rate, the respondents were contacted four times through a pre-notice letter, the survey questionnaire, a reminder letter or acknowledgement letter, and replacement letter. The final year VAE preservice teachers from a public university in Malaysia were identified as target participants of this study. Due to the pandemic COVID-19 outbreak and the MCO restriction, these preservice teachers have experience online teaching and learning approach for two consecutive 
years, which nearly a year. Out of 158 number of pre-service VAE teachers targeted, only 122 VAE pre-service teachers responded (77.2 percent response rate), thus become the respondent of this study. The questionnaire survey consisted of two main sections. The first section comprises of ten items that sought to determine the impact of online learning towards pre-service teachers' learning process. These items were adopted from a questionnaire by Kapasia et al. (2020). Pre-service teacher's responses were treated as a binary based on their agreement and disagreement toward statement enquired. On the other hand, the second section consisted of 12 items, where three questions for each construct which focuses on scale measuring the variables of the study. All items from this section were rated through a five-point Likert-type scale and were adopted from the TAM questionnaire (Davis, 1989). In regard to data analysis, a confirmatory factor analysis (CFA) was carried out to established factorial validity of items for each construct. On the other hand, SPSS was employed to analyzed descriptive data, while the Partial Least Squares (PLS) of variance-based Structural Equation Modelling (SEM) was used to test the research hypotheses of the study. As a technique that applied a multivariate statistical analysis, SEM was useful in representing translations of series of hypothesized cause-effect relationship between variables (Hair et al., 2017).

\section{Research Findings}

Analysis of the data in this study was conducted in three phases, namely the descriptive analysis, the measurement properties, and the structural model. The descriptive analysis was carried out to determine the impact of online learning toward VAE pre-service teachers' quality of learning. On the other hand, the measurement properties were carried out to examine the convergent validity and discriminate validity of the measurement item used, and the structural model was assessed to determine the contributions of the constructs and addressing the research hypotheses of the study.

\section{The Effect of Online Learning toward VAE pre-service Teachers' Quality of Learning}

In this section, ten items or statements were tested under the aimed to examine the impact of online learning toward VAE pre-service teachers' learning process during the COVID-19 pandemic. Responses gained from all the items were firstly accessed through frequencies ( $n$ ) and percentage, before the total percentage (average) of each category were compared and reported. 
INTERNATIONAL JOURNAL OF ACADEMIC RESEARCH IN PROGRESSIVE EDUCATION AND

DEVELOPMENT

Vol. 10, No. 3, 2021, E-ISSN: 2226-6348 @ 2021 HRMARS

Table 1: The Effect of Online towards toward VAE pre-service Teachers' Quality of Learning during the COVID-19 pandemic

\begin{tabular}{|l|l|l|l|l|}
\hline \multirow{2}{*}{ Statement } & \multicolumn{3}{l|}{ Yes } & \multicolumn{2}{l|}{ No } \\
\cline { 2 - 5 } & $\mathbf{n}$ & $\mathbf{\%}$ & $\mathbf{n}$ & $\mathbf{\%}$ \\
\hline $\begin{array}{l}\text { I get stressful while study online during the COVID-19 } \\
\text { pandemic }\end{array}$ & 87 & 71.3 & 35 & 28.7 \\
\hline I afraid that online learning will decrease my creativity & 85 & 69.7 & 37 & 30.3 \\
\hline Online learning during COVID-19 pandemic burden me & 72 & 59.1 & 50 & 40.9 \\
\hline $\begin{array}{l}\text { I feel more stress during online learning than face-to- } \\
\text { face learning }\end{array}$ & 74 & 60.7 & 48 & 39.3 \\
\hline $\begin{array}{l}\text { I feel difficult to discuss with friend while online } \\
\text { learning }\end{array}$ & 89 & 72.9 & 33 & 27.1 \\
\hline I feel difficult to concentrate during online class & 93 & 76.2 & 29 & 23.8 \\
\hline I feel unmotivated during online learning & 87 & 71.3 & 35 & 28.7 \\
\hline I lost my interest to study while online learning lesson & 75 & 61.5 & 47 & 38.5 \\
\hline $\begin{array}{l}\text { I feel difficult to do a group work assignment with my } \\
\text { friend during online learning }\end{array}$ & 74 & 60.7 & 48 & 39.3 \\
\hline $\begin{array}{l}\text { I feel hard to understand the lecturer's instruction } \\
\text { during online class }\end{array}$ & 80 & 65.6 & 42 & 34.4 \\
\hline
\end{tabular}

Note: $n=122$

The result from Table 1 indicates that the VAE pre-service teachers' quality of learning is affected by online learning during the COVID-19 pandemic. The highest total percentage was recorded on pre-service teacher's concentration, where majority of them (76.2\%) agreed that they feel difficult to concentrate during online class. The VAE pre-service teachers also reported that they are having difficulties to discuss with their friends $(72.9 \%)$, unmotivated (71.3\%), and stressful (71.3\%) while study online during the COVID-19 pandemic. Interestingly, most of the respondents (69.7\%) afraid that adoption of online might decreased their creativity. Basically, these results concluded that the VAE pre-service teachers' quality of learning were affected by adoption of online learning during the COVID-19 pandemic.

\section{Assessment of the Measurement Properties}

The convergent validity was employed in assessing the stability and consistency of the survey items, for each deigned construct. Under that objective, the composited reliability $(\mathrm{CR})$, average variance extracted ( $\mathrm{AVE}$ ) and discriminate validity of each construct were examined. As presented in Table 2, the CR of each construct that was assessed using Cronbach' alpha was ranged from 0.82 to 0.93 does exceeded the recommended threshold value (White et al, 2012). Similarly, the AVEs index that exceed 0.50 cut-off point does indicates the adequate for each construct are adequate for testing structural equation modelling. This finding also informed that more than one-half of the variance observed in the items was accounted for their hypothesized factor. 
Table 2: Composite Reliability, and the Average Variance Extracted (AVE) of Constructs

\begin{tabular}{|l|l|l|}
\hline Constructs & $\begin{array}{l}\text { Average Variance Extracted } \\
\text { (AVE) }\end{array}$ & $\begin{array}{l}\text { Composite Reliability } \\
\text { (CR) }\end{array}$ \\
\hline Perceived Usefulness (PU) & 0.90 & 0.93 \\
\hline Perceived Ease of Use (PEOU) & 0.77 & 0.88 \\
\hline Attitude (ATT) & 0.75 & 0.84 \\
\hline Behavioral Intention (BI) & 0.66 & 0.82 \\
\hline
\end{tabular}

Further, the discriminant validity analysis was carried out to assess the degree to which items of a particular scale measure its own constructs. In determining the discriminant validity of the measurement model, the square roots of the AVE should be larger than its correlation with other constructs (Hair et al., 2017). As referred to Table 3, all constructs have met the recommendation, thus confirming that discriminant validity was acceptable.

Table 3: Correlation of latent and square roots of AVE constructs

\begin{tabular}{|l|l|l|l|l|}
\hline Variables & PU & PEoU & ATT & BI \\
\hline Perceived Usefulness (PU) & 0.93 & & & \\
\hline Perceived Ease of Use (PEOU) & 0.67 & 0.91 & & \\
\hline Attitude (ATT) & 0.55 & 0.48 & 0.90 & \\
\hline Behavioral Intention (BI) & 0.54 & 0.45 & 0.48 & 0.89 \\
\hline
\end{tabular}

\section{The Structural Model}

The structural model was employed in determining the cause-effect relationship between predictor and predicted constructs of the study. For that reason, the path coefficient (B) value was determined in assessing the significance of the path coefficient between constructs, while the coefficient of determination $\left(R^{2}\right)$ value was used to determine the explanatory powers of the model.

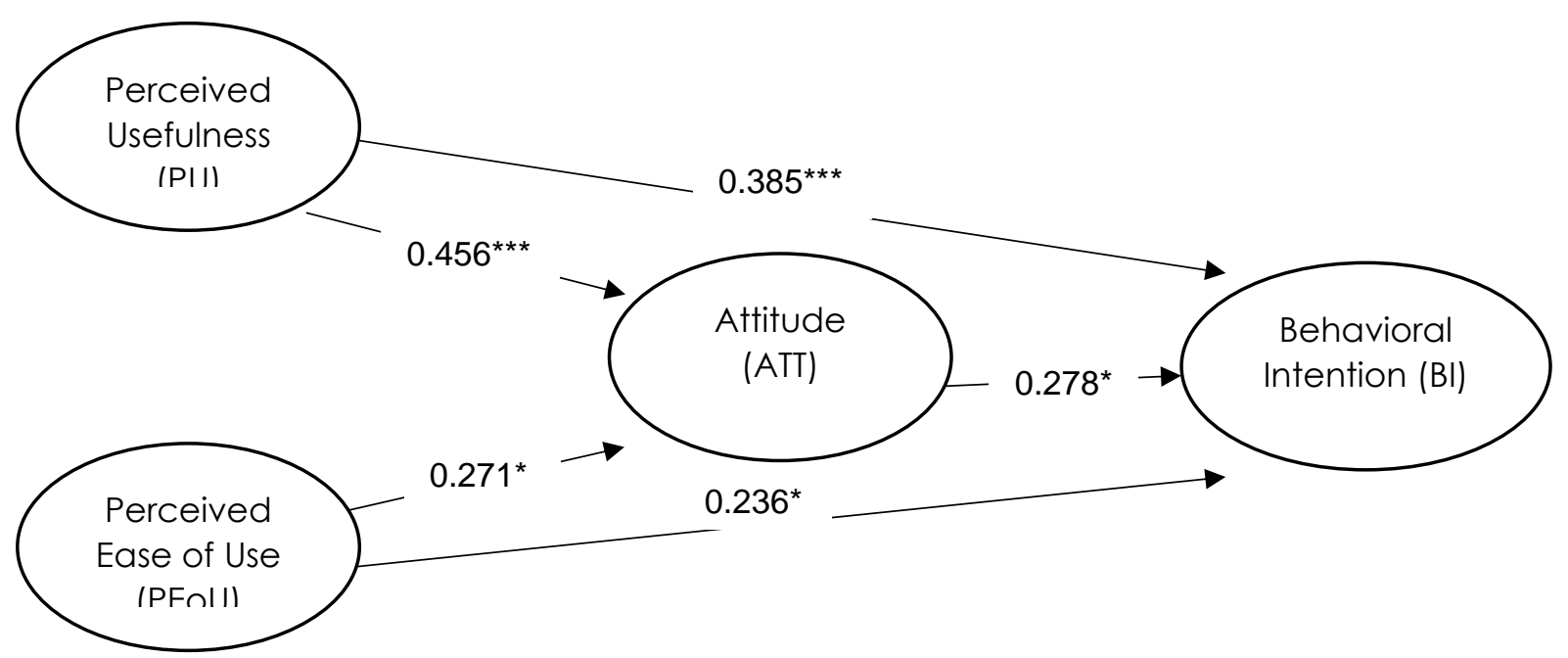

Note: $* * * p<0.001 ; * p<0.05$

Figure 1: The Structural Model Depicting Significant Pathways

As shown in Figure 1, the strongest direct impact was found on the relationship between pre-service teacher's PU toward their ATT $(B=0.456, t=7.52, p<0.001)$. A strong direct impact was also found on the relationship between pre-service teacher's PU toward 
their $\mathrm{BI}(\mathrm{B}=0.385, \mathrm{t}=7.27, \mathrm{p}<0.001)$. The direct relationship between pre-service teacher's PEoU toward ATT $(B=0.271, t=2.62, p<0.05)$, ATT toward $B I(B=0.278, t=2.69, p<0.05)$, and $\mathrm{PEoU}$ toward $\mathrm{BI}(\mathrm{B}=0.236, \mathrm{t}=2.58, \mathrm{p}<0.05)$ were also reported to be significant. These findings thus indicated that all research hypotheses were accepted, except for the first hypothesis $\left(\mathrm{H}_{1}\right)$. Figure 1 also used in estimating the explanatory power of the structural model, through calculating its' coefficient of determination $\left(R^{2}\right)$ pf the predicted constructs. As presented, pre-service teacher's ATT was reported to be significantly determined by their $P U$ and PEoU, resulting $R^{2}$ value of 0.428 . This finding indicates that pre-service teacher's $P U$ and PEoU explained 42.8 percent of the variance of their attitude toward adopting online learning. Conversely, the findings inform that the model accounted for 31.1 percent of the variance in pre-service teacher's $B I\left(R^{2}=0.311\right)$.

\section{Research Discussion and Conclusion}

To explore the factors in predicting the ATT and $\mathrm{BI}$ towards online learning during COVID-19, an adopted Technology Acceptance Model (TAM)has been successfully helpful to explain the circumstances perceived by VAE pre-service teachers from a public university in Malaysia. The instrument of a questionnaire has been utilized in data collection process. Through the composite reliability, AVE of constructs and discriminant validity, the structural model is reported to be reliable and valid as it able to achieve the recommended threshold value accordingly.

Regarding the effect of online learning, there are certain circumstances that been raised up and should be considered in order to enhance the quality in online learning. This includes difficulties to concentrate in learning, difficulties to have discussion with friends, unmotivated and stress. Despite that, these concerns do not hinder VAE pre-service teachers to gain benefits and perceive positive attitude towards online learning during this pandemic. This can be confirmed when results from PLS-analysis revealed that PU has a positive relationship towards VAE teachers' $A T T$ and $B I$. This result able to confirm the $2^{\text {nd }}$ and $3^{\text {rd }}$ hypotheses of the study. It can be inferred that the use of online learning is beneficial and useful for VAE pre-service teachers during this pandemic. The significant of PU allowing individuals to complete their tasks with high quality, improve effectiveness while doing the tasks and makes it easier to complete (Jetter et al., 2018). In correlation to this study, the use of online learning would benefit VAE pre-service teachers to learn in effective ways, increase their performance in learning as well as helps them to achieve their expected success. All these pleasant feelings play a major role in contributing to the positive ATT perceived by VAE teachers and thus enhance their $\mathrm{BI}$ in adopting online learning effectively during this pandemic. In normal time, PU was also reported to significantly predict ATT (Nadlifatin, et al., 2020) and BI (Shao, 2019; Thongsri et al., 2019).

Despite of this positive relationships of PU towards ATT and BI, this present study does not able to confirm the significant of PU and PEoU in $1^{\text {st }}$ hypothesis. This present finding contradicts with study by Sukendro (2020) that suggests, the learners' feelings toward the advantages of the online learning during COVID-19 is improved when online learning is perceived to be user friendly. It is possible to state that the path coefficient $(B)$ value and coefficient of determination $\left(R^{2}\right)$ value might be different (increase or decrease) if there is the relationship between PU and PEoU. The possible reason to the insignificant between PU and 
PEoU is regarding the level of experiences among VAE pre-service teachers towards the use of online learning before the pandemic of COVID-19. It is believed, the PU of particular technology be a major concern among individuals with high experience towards the technology, while those who are less experiences would give a concern on the PEoU (Taylor \& Todd, 1995). In other words, VAE pre-service teachers that less experiences in using online learning before the pandemic of COVID-19 may perceive difficulty to use online learning.

In conclusion, the education system was affected due to the COVID-19 outbreak, and the conventional face-to-face learning approach was shifted to online learning approach in preventing the spread of the virus. This change has led to the modification in term of the curriculum and the learning process among VAE pre-service teachers since online learning appears as the most practical learning approach during this pandemic. Undoubtedly, the use of online learning may disrupt VAE pre-service teachers' creative abilities and critical thinking skills as they can't experience certain art process in the real world. Instead, they go through the process of simulation in which not a common practice in art classroom. Hence, the modification in curriculum should be more focus on its usefulness and ease of use to be implemented in online art classrooms. The use of online learning platform should be easy to use to reduce VAE pre-service teachers' cognitive load and directly reduce the chances to obtain technostress. The platform also should be practical, beneficial and enables them to perform in completing their learning tasks. All these practical features may help them to perceive a good attitude and pleasant experiences in using online learning. The main reason why the ease of use and usefulness of online learning platform need to be emphasized because, the way pre-service teachers perceive online learning (pleasant or unpleasant) preservice teachers is rely on it. Their pleasant feeling is important to ensure they always feels motivated and eager to learn despite any challenges faced throughout the online learning process. In addition, there are several suggestions that authorities may consider in enhancing the effectiveness of online learning. Specific guidelines need to be provided by authorities to facilitate the effectiveness of online learning especially in art classroom. The authorities also need to consider VAE pre-service teachers technical and moral support towards the successful of online learning adoption in art classroom. This includes the VAE pre-service teachers' internet connection, personal computer performance and mental capacity throughout the online learning process. The duration of time in learning also should be appropriate as the attention span during online learning may lesser than the conventional learning setting. Although it is a bit challenging to set the standardize learning duration during online learning, but it is essential to be considered in reducing the technostress among students and educators. It is foreseen that the findings and suggestions from this study will contribute toward understanding of impact of online learning toward VAE pre-service teacher's training process and students in general. It is also hoped that this study will act as a guide for teachers training institutions and the Ministry of Higher Education toward establishing a standard of successful online learning adoption.

\section{References}

Aburagaga, I., Agoyi, M., \& Elgedawy, I. (2020). Assessing Faculty's use of Social Network Tools in Libyan Higher Education via a Technology Acceptance Model. IEEE Access, 116415116430. 
Azman, M. N., Kamis, A., Kob, C. C., Abdullah, A. S., Jerusalem, M. A., Komariah, K., \& Budiastuti, E. (2020). How Good is MyGuru: The Lecturers' Perceived Usefulness and Attitude. Cakrawala Pendidikan, 422-431.

Berrocoso, J. S., Garrido-Arroyo, M. C., Burgos-Videla, C. \& Morales-Cevallos, M. B. (2020). Trends in Educational Research about e-Learning: A Systematic Literature Review (2009 - 2018). Sustainability, 12, 1-23.

Davis, F. D. (1989). Perceived Usefulness, Perceived Ease of Use, and User Acceptance of Information Technology. Management Information Systems Research Center, 319340.

Dilmac, S. (2020). Students' Opinions about the Distance Education to Art and Design Courses in the Pandemic Process. World Journal of Education , 113-125.

Hair, J. F., Hult, G. M., Ringle, C. M., \& Sarstedt, M. (2017). A Primer on Partial Least Squares Structural Equation Modelling (PLS-SEM). London: SAGE Publication.

Hogan, J., Jaquith, D., \& Gould, L. (2020). Shifting Perceptions of Quality in Art Education. Art Education, 8-13.

Jetter, J., Eimecke, J., \& Rese, A. (2018). Augmented reality tools for industrial applications: What are potential key performance indicators and who benefits? Computer in Human Behavior, 18-33.

Mohd Khairezan Rahmat (2020). From Pencil to Pixel: Factor Influencing Visual Art Education (VAE) Teacher's decision toward Incorporating Technology into Art Classrooms. International Journal of Education and Pedagogy, 2(4), 84-93.

Mukminin, A., Habib, A., Muhaimin, M., \& Prasojo, L. D. (2020). Exploring the Drivers Predicting Behavioral Intention to Use m-Learning Management System: Partial Least Square Structural Equation Model. IEEE Access, 181356-181356 .

Nadlifatin, R., Ardiansyahmiraja, B., Persada, S. F., Belgiawan, P. F., Redi, A. P., \& Lin, S.-C. (2020). The Measurement of University Students' Intention to Use Blended Learning System through Technology Acceptance Model (TAM) and Theory of Planned Behavior (TPB) at Developed and Developing Regions: Lessons Learned from Taiwan and Indonesia. International Journal of Emerging Technologies in Learning, 219-230.

Nizar, N. N., Rahmat, M. K., \& Damio, S. M. (2020). Evaluation of Pre-service Teachers' Actual Use towards Augmented Reality Technology through MARLCardio. International Journal of Academic Research in Business and Social Sciences, 1092-1101.

Pratama, U. N., \& Surahman, E. (2020). Investigating Student Responses of Online Learning During the Covid-19 Pandemic in Performing Art Education. 2020 6th International Conference on Education and Technology (ICET) (pp. 64-69). New York: IEEE Conference Proceeding.

Sajnani, N., Mayor, C., \& Tillberg-Webb, H. (2020). Aesthetic presence: The role of the arts in the education of creative arts therapists in the classroom and online. he Arts in Psychotherapy, 1-40.

Sands, L., \& Purtee, M. (2018). The Open Art Room. Worcester: Davis Publication.

Schlenz, M. A., Schmidt, A., Wostmann, Kramer, N. \& Weidner, N. S. (2020). Students' and lecturers' perspective on the implementation of online learning in dental education due to SARS-CoV-2 (COVID-19): A cross-sectional study. BMC Medical Education. 20(1), 354-366. 
Shao, C. (2019). An Empirical Study on the Identification of Driving Factors of Satisfaction with Online Learning Based on TAM. Advances in Economics, Business and Management Research, 1067-1073.

Sukendro, S., Habibi, A., Khaeruddin, K., Indrayana, B., Syahruddin, S., Makadada, F. A., \& Hakim, H. (2020). Using an extended Technology Acceptance Model to understand students' use of e-learning during Covid-19: Indonesian sport science education context. Heliyon, 1-9.

Taylor-Guy, P., \& Chase, A.-M. (2020, March 25). Universities need to train lecturers in online delivery, or they risk students dropping out. The Conversation, pp. 1-5.

Taylor, S., \& Todd, P. (1995). Assessing IT Usage: The Role of Prior Experience. MIS Quarterly, 561-570.

Thongsri, N., Shen, L., \& Bao, Y. (2019). Investigating Factors Affecting Learner's Perception Toward Online Learning: Evidence from ClassStart Application in Thailand. Behaviour and Information Technology, 1-17.

White, G., Cordato, D., O'Rourke, F., Mendis, R., Ghia, D., \& Chan, D. (2012). Validation of the Stroke Rehabilitation Motivation Scale: A Pilot Study. Asian Journal of Gerontology \& Geriatrics, 80-87. Winder

Yeop, M. A., Yaakob, M. M., Wong, K. T., Don, Y., \& Zain, F. M. (2019). Implementation of ICT Policy (Blended Learning Approach): Investigating Factors of Behavioural Intention and Use Behaviour. International Journal of Instruction, 767-782. 